\title{
How the COVID-19 Crisis Is Showing Us the Complexities in the Global Energy Transition
}

\author{
Carlos Germán Meza ${ }^{1, *}$, Nilton Bispo Amado² and Ildo Sauer ${ }^{2}$ \\ 1 Postdoctoral researcher, Institute of Energy and Environment, University of Sao Paulo; \\ mezagonzalez@usp.br (C.G.M.) \\ 2 University of Sao Paulo, Institute of Energy and Environment; nilton@iee.usp.br (N.B.A.); \\ illsauer@iee.usp.br (I.S.). \\ * Correspondence: mezagonzalez@usp.br; Tel.: +55 11968640932
}

\begin{abstract}
The measures for tackling the COVID-19 may shrink the global GDP by approximately 6\% in 2020, the deepest post-war recession. As a result, the global energy demand declined by $3.8 \%$ in the first quarter of 2020. Concerning fossil fuels, this conjuncture reduced the demand drastically and collapsed the prices to historic levels. Despite the general market disruptions, renewable energy sources (RES) seem to be more resilient to the crisis because they are the only sources that will grow in demand in 2020, driven by priority dispatch. The RES's significant growth in cumulative installed capacity in the last two decades and the significant cost reductions of RES and energy storage technologies are positive signs towards better market conditions for the global energy transition. Currently, the crisis is seen by international agencies and transition scholars as an opportunity to advance a renewable-based energy transformation. Nevertheless, this article aims at caution about another possibility: if societal changes are not urgently implemented, the crisis may weaken the global energy transition. This article examines this last possibility from a three-level perspective: 1) post-COVID economic recovery, 2) low oil and natural gas prices and competitiveness of alternative sources and, 3) reorganization of the world energy market and the OPEC+. This paper exists to stimulate debate.
\end{abstract}

Keywords: renewable energy; decarbonization; fossil fuels; energy transition; COVID-19; sustainability

\section{Introduction}

The measures for tackling the COVID-19 may shrink the global GDP by approximately $6 \%$ in 2020 [1], the deepest post-war recession. As a result, the global energy demand declined by $3.8 \%$ in the first quarter of 2020 and coal $(-8 \%)$, oil $(-5 \%)$, and electricity $(-20 \%$ or more during periods of lockdown in several countries) were the ones that received the most remarkable impacts [1]. Concerning fossil fuels, this conjuncture reduced the demand drastically and collapsed the prices to historic levels. Thus, the profits of the fossil fuel industries and oil-exporting countries have been affected. One of the positive environmental impacts of the crisis is that global $\mathrm{CO} 2$ emissions will fall between $4 \%$ (if pre-pandemic conditions return by mid-June) and $7 \%$ (if some restrictions remain worldwide until the end of 2020) [2]. Despite the general market disruptions, renewable energy sources (RES) seem to be more resilient to the crisis because they are the only sources that will grow in demand in 2020, driven by priority dispatch [1]. The RES's significant growth in cumulative installed capacity in the last two decades and the significant cost reductions of RES (Fig. 1) and 
energy storage technologies ${ }^{1}$ [3] are positive signs towards better market conditions for the locals and global energy transition (hereafter, energy transition) ${ }^{2}$.

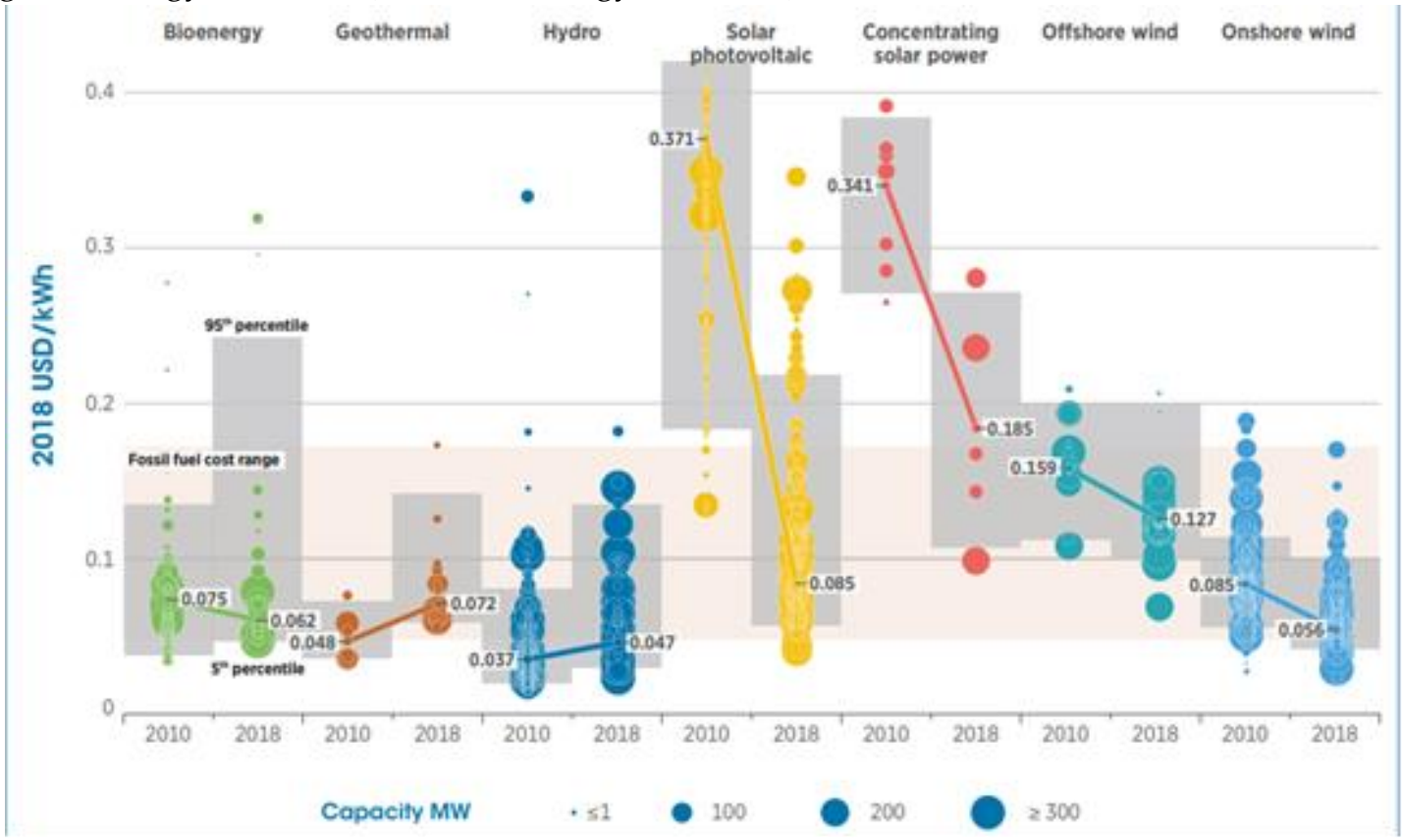

Figure 1. Global Levelized costs of electricity (LCOE) of utility-scale renewable power generation technologies, 2010-2018. Source: IRENA [4].

IRENA [5] recently developed a renewable energy roadmap to reactive the global economy after the COVID-19 crisis. Also, the crisis is seen by other international agencies as an opportunity to advance a renewable-based energy transformation "to meet international climate goals while boosting economic growth, creating millions of jobs, and improving human life" [6]. Indeed, societal changes during and after the COVID-19 crisis could reorient the global economy towards a more sustainable development path [7]. Nevertheless, this article aims at caution about another hypothesis: if societal changes (e.g., institutional, political, cultural, and socioeconomic) are not urgently implemented, the COVID-19 crisis may impair the energy transition. We explore this last possibility from a three-level perspective based on systemic structural dynamics: 1) post-COVID economic recovery, 2) low oil and natural gas prices, and how they may affect the penetration of alternative sources, and 3) reorganization of the world energy market and the OPEC+. However, up until now, neither long-term immunity nor vaccine has been developed. Thus, section 5 briefly comments on the possibility of the energy transition in a new "normal" reality using recent insights of Kanda and Kivimaa [8]. Section 6 concludes with the final reflections.

\section{Energy transition and post-COVID economic recovery}

On a global scale, there is no sign of absolute decoupling of economic growth and the growth of energy use [9,10] and $\mathrm{CO}_{2}$ emissions [11]. Historically, economic recoveries after pandemic crises

\footnotetext{
${ }^{1}$ Especially lithium-ion batteries.

2 The global primary energy transition is understood here as the renewable-based energy transformation of the primary energy consumption at a global scale, emphasizing the role of the 'modern' renewables technologies (mainly solar and wind) to displace fossil fuels (oil, coal and natural gas). Defining our scope of analysis is essential because there are different scales of transitions (local, community, national, regional, global) and different layers of energy systems (e.g., primary energy consumption, final energy demand, end-use technologies) [43].
} 
increased the global energy demand rapidly (Fig. 2). The relationship between economic growth and the growth of energy use is weaker than in past crises $[9,10]$, but it is still robust. Hence, we should expect a rebound in global energy use in a post-COVID economic recovery. We do not know the duration of the crisis and the intensity of the economic recovery. Even if it is a prolonged deep economic downturn [12], the main point is that faster the global energy demand will rise in the forthcoming economic recovery, the more difficult it will be supplying a significant fraction of it with renewables, and $\mathrm{CO}_{2}$ emissions could rebound and get back to its long-run growth trajectory $[1,2,5]$.

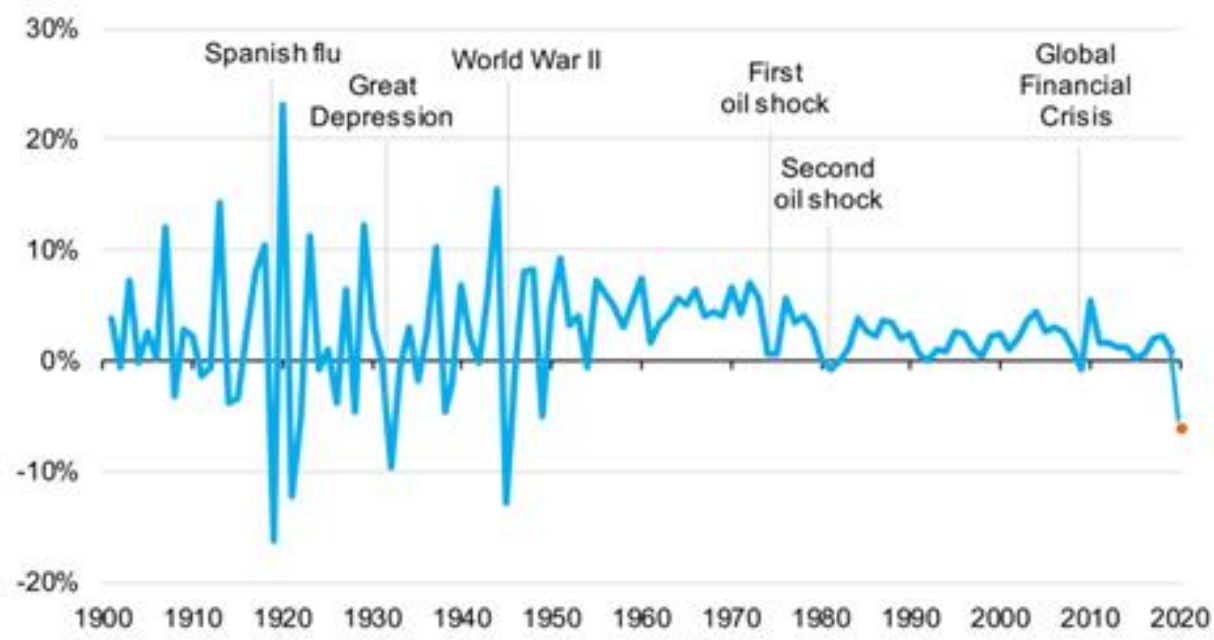

Figure 2. Rate of change in global primary energy demand, 1900- 2020. Source: Ref. [1].

In 2012, RES (mainly wind, solar, and geothermal; excluding hydro) accounted for nearly $3 \%$ of the primary world energy consumption [13]. Seven years later, modern RES accounts for $5 \%$ of the primary world energy consumption (overcoming nuclear participation for the first time) [14]. Despite the significant growth in global cumulative installed capacity, the participation of RES in the world energy consumption is still low because of the growth in energy demand. However, economic recovery is necessary for the energy transition, and investments in RES and efficiency are necessary for a cleaner economic recovery. For instance, China is a coal-based economy, but it is also "the world leader in both manufacturing and uptake of photovoltaics" [15], and a global producer of other renewable technologies such as wind turbines and batteries [16].

\section{Low oil and natural gas prices and energy transition}

\subsection{Transport sector}

The most significant impact of COVID-19 by far is on the public transport sector, especially air travel. In normal conditions, fuel and travel demands tend to increase with lower fuel prices and decrease with lower incomes, ceteris paribus $[17,18]$. Naturally, to the extent that quarantines and restrictions are maintained, the demand for transport will remain low because a significant part of the population prioritizes remote activities and individual mobility for short distances travels. Thus, electric vehicles (EVs) could eventually be favored by this tendency towards individual mobility for short distances [8]. However, some recent studies have shown that persisting low oil prices can damp electric mobility. Baur and Todorova [19] (p. 261) indicate "there is a substitution effect in place between traditional cars and electric cars partially driven by the price of oil. Thus, persisting low oil price levels and higher demand for less fuel efficient cars may not only have adverse environmental consequences but can also dampen the growth potential of electric vehicle manufacturers." Similar results point in the same direction from consumers' perspectives [20,21]. Finally, one of the factors that contribute the most to the growth of electric mobility is direct and 
indirect subsidies and incentives [20-22]. It is unclear how the crisis may affect the capacity of the governments to establish new taxes on fuels and to maintain or increase policies to promote electric mobility.

\subsection{Electricity sector}

Cheap natural gas is relevant for the electricity sector because current generation costs of the natural gas Combined-cycle plants (NGCC) are approximately $15 \mathrm{US} \$ / \mathrm{MWh}^{3}$. The generation costs and LCOEs associated with these low fuel prices are an economic incentive to burn natural gas. It is premature to confirm, but current low oil and natural gas price levels (since 2014), volatility and uncertainties could be factors that may dampen the growth potential of RES. Figure 3 shows the global net additions of renewable capacity growth of wind, solar, and geothermal sources and the average oil prices (2001-2019). During 2001 and 2014 (period of the oil price boom), the average net addition growth was $19 \%$ p.a. $(\sigma=3 \%)$. From 2015 to 2019 , the average net addition growth was $15 \%$ p.a. $(\sigma=2 \%)$ coinciding partially with a sharp decline in oil prices and despite the plummeting prices of the RES (except for geothermal). In 2020, net additions of renewable electricity capacity may decline by $18 \%$ compared with 2019, and a rebound in new installations (10\%) is expected in 2021 [23].

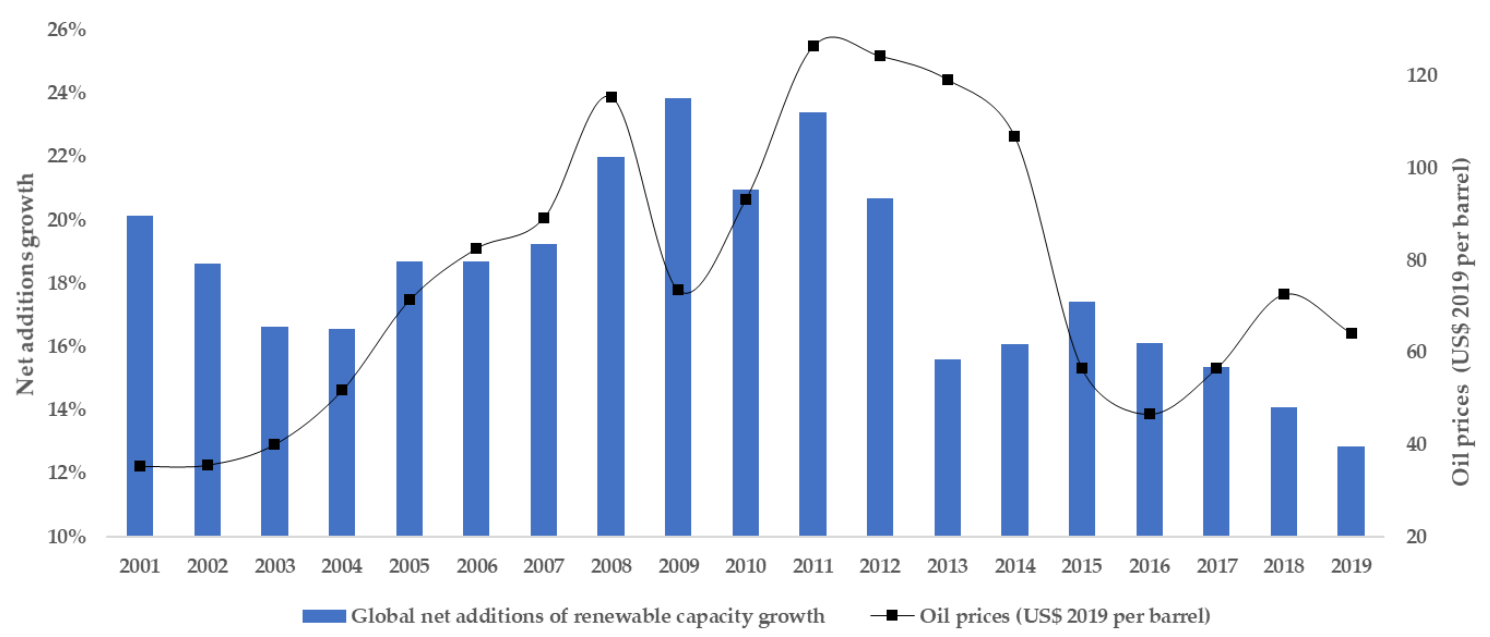

Figure 3. Global net additions of renewable electricity capacity growth (wind, solar and, geothermal) and average oil prices (US\$ 2019 per barrel), 2001-2019. Source: own elaboration with data retrieved from Ref. [14].

Recent results using a time-series approach indicate that oil price affects renewable energy investment in the USA and Norway, but not in the UK [24]. Moreover, Cao, Guo, and Zhang [25] provide evidence that the scale of investments of Chinese renewable energy firms (wind, solar, and biomass) is affected by oil price uncertainty. Nevertheless, more original research, systematic reviews, and meta-analyses are needed on these topics because the role of RES on the energy mix is recent (the 2000s), and the sharp decline in oil prices is even more recent (2014-2020). Besides, in countries where there is little support for the renewable energy sector, the investment will be more

\footnotetext{
${ }^{3}$ Calculations are made considering a fuel price of $2 \mathrm{US} \$ / \mathrm{MMBtu}$ and a Heat rate of $6431 \mathrm{Btu} / \mathrm{kWh}$. Besides, NGCC plants provide other essential services for the electricity sector, such as firm capacity, dispatchable power, and ancillary services.
} 
dependent on macroeconomic aspects as well as substitutes such as oil [24]. Finally, there is no consensus about the impact of oil price behaviors on clean stock markets [26,27], and the effect of oil prices on green assets appears to be statistically insignificant [28].

\subsection{Food production: fertilizers}

Typically neglected, decarbonization of fertilizers for agricultural production may also be a compelling case to note. The dominant process to produce ammonia involves the steam methane reformation (SMR) of fossil fuels (mainly natural gas and coal) to produce commercial bulk hydrogen (H2). However, the implementation of non-CO2 emitting sources of the $\mathrm{H} 2$ for nitrogen fertilizer production could be a technological option to produce renewable fertilizers. Currently, the most mature technological option is to use an electrolyzer system to split water $(\mathrm{H} 2 \mathrm{O})$ into hydrogen (H2) and oxygen using renewable electricity (Figure 4).

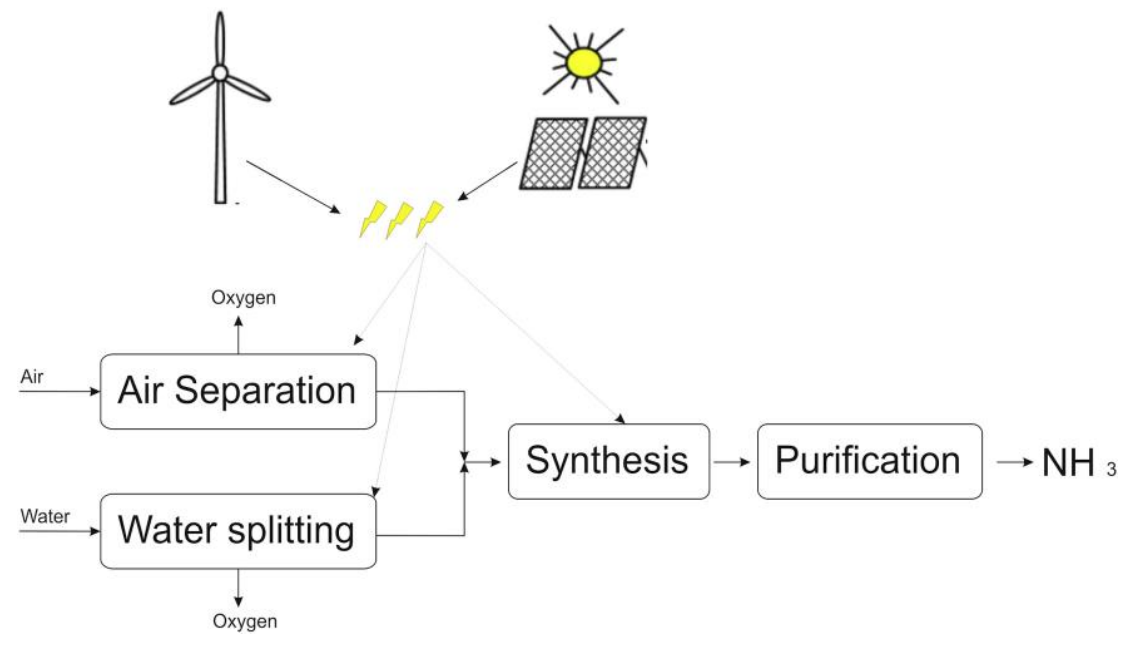

Figure 4. Process flowsheet. Source: Ref. [29].

Still, fossil-free ammonia entails higher costs than conventional fossil fuel-based ammonia [29], and relatively cheap natural gas and coal do not enhance the potential competitiveness in the face of the conventional one. Observed lower prices of fossil fuels and conventional fertilizers tend to diminish the food costs and prices (Fig. 5). If others COVID-19 global waves are avoided [30], lower prices of fertilizers might partially counterbalance the negative impact of the COVID-19 crisis on global food security. However, they also reduce the economic incentives to decarbonize the food production in the short-term. 


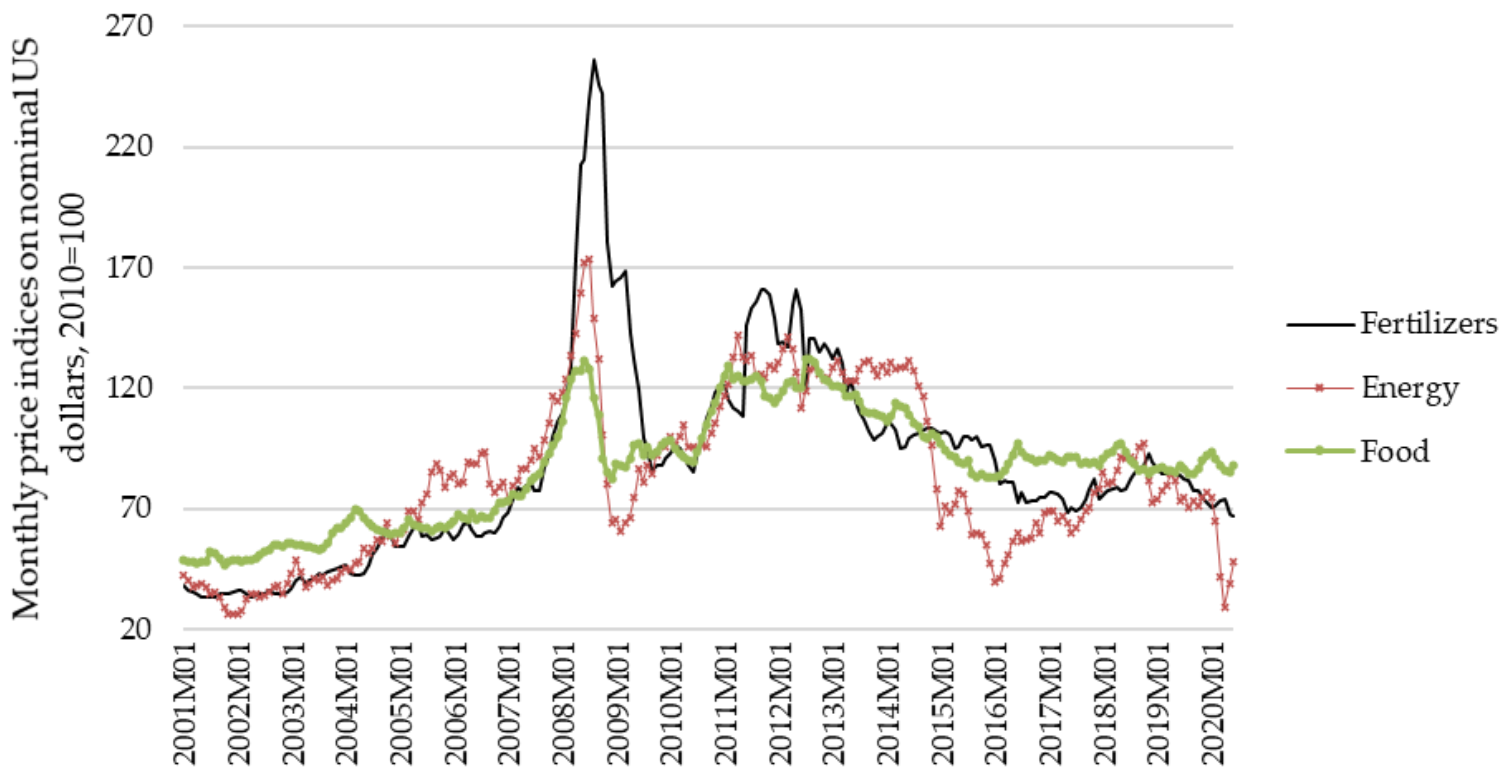

Figure 5. Monthly price indices of fertilizers, energy, and food on nominal US dollars, $2010=100$, 2001 to June 2020. Source: own elaboration based on Ref. [31].

\section{Will the OPEC+ emerge more influential in the post-COVID-19 economy?}

Recent results using mathematical models of strategic interactions suggest that oil players (mainly OPEC) may exhibit limit-pricing behaviors regarding RES [32-34]. Figure 6 shows the production costs curve of liquid supply (axis $\mathrm{x}$ ) versus recoverable quantities (axis y). Except for OPEC oil, low oil prices (e.g., 25-30 US\$/barrel) make all fuel options (including alternatives fuels such as Gas-to-Liquids, coal liquefaction, and biofuels) economically unviable. In the case of non-conventional oil options, recent estimates indicate that the production costs of shale oil, Brazilian pre-salt, and oil sands are approximately 30 US\$/barrel [35], 14.3 US\$/barrel [36] and 50 US\$/barrel [37], respectively. These non-conventional industries are also affected by prices below or nearly the production costs. Thus, the OPEC+ could emerge from the pandemic stronger than its competitors in the energy markets. This implication is crucial because the market power of an articulated OPEC+ may affect the energy transition through production and price shocks.

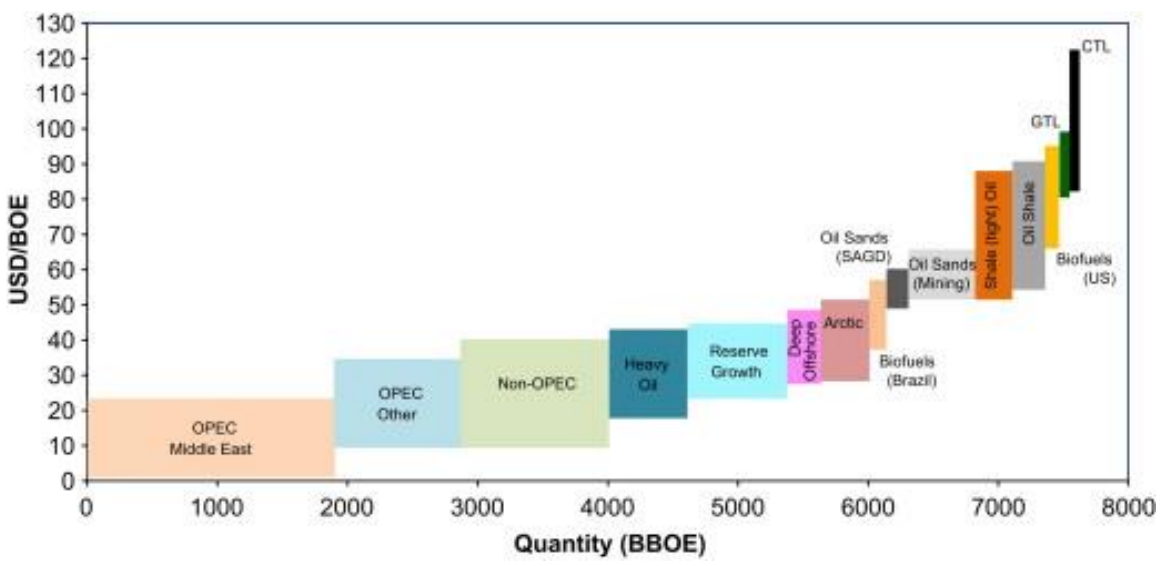

Figure 6. Liquid supply cost curve showing production costs (axis-x, US\$/BOE) versus recoverable quantities (axis-y, BBOE). Source: Ref. [38].

\section{Energy transition in a new "normal" energy reality}


What if long-term immunity is not developed, and it takes much longer than expected to create an effective vaccine? This scenario imposes a new "normal" energy reality and requires a new -and little know- spectrum of analysis. Kanda and Kivimaa [8] claim that permanent impacts of the pandemic may affect public mobility options such as air travel and change mobility patterns (e.g., due to the teleworking practices). Thus, the energy demand for transport and other sectors such as the tertiary sector could be maintained at low levels, while domestic electricity demand increases. If the recommendation is to avoid public mobility, transport and urban planning policies should be enhanced to address this new reality. The priority should be low-income and middle-income workers that must work in their workplace and travel mainly by collective transport. Many more efforts should be made to address these challenges in large cities in underdeveloped countries with high poverty rates (e.g., Sao Paulo, Mexico City).

The impacts of the pandemic on the electricity sector seem to be more challenging to predict. If aggregate electricity demands persist low, the share of renewable generation can be significantly increased $^{4}$ [8]. However, depending on the regulatory structure of each region or country, the reduction in electricity demand may raise concerns regarding the potential transfer of costs to consumers through increased tariffs to compensate for income losses; putting pressure on governments to maintain or establish new subsidies in a context of a reduced collection of taxes (see Ref.[39,40] for the Brazilian and Indian cases). Also, if teleworking at home will be part of the new "normal", who should pay for increased domestic electricity bills? As Kanda and Kivimaa stated, "this [type of consideration] points attention to the importance of analyzing the implications of the pandemic on sustainability transitions from the perspective of social justice.” Ref. [8], p. 4.

\section{Conclusions}

The terrible COVID-19 crisis is offering to transition scholars an opportunity to improve the understanding of sustainable transitions. In this article, we suggest that -if there are no significant societal changes-post-COVID economic recovery and low fossil fuel prices may impair the energy transition. Moreover, due to the low production costs and massive reserves, probably the most resilient energy player in the face of the crisis is the OPEC+. Our approach emphasizing economic dynamics allows us to suggest at least two research streams: the OPEC+ decisions (production, prices, and the linkage with economic growth) as a parameter of control of the energy transition, and how underdeveloped countries should address the pandemic crisis to accelerate the sustainable transitions. In general, the challenge is to reduce or eliminate the influence of systemic forces that decelerate the energy transition using sound energy policies but considering the potential trade-offs and unintended consequences [41,42].

Naturally, innovation and policies to continue reducing costs of RES and energy storage technologies are essential. However, the transition to RES would require significant shifts "in political regulations, tariffs and pricing regimes, and the behavior of users and adopters" [43]. Removing massive subsidies and internalizing externalities of fossil fuels [44] can further enhance the competitiveness of RES and electric mobility, contributing to the penetration of these alternatives. On the one hand, these policies can be particularly challenging to execute in the context of a pandemic or economic recovery because they could be considered procyclical. On the other hand, it is the opportunity to think, better understand and, eventually carry out new proposals such as the Green New Deal (e.g.) [7,45] to fast-track decarbonization, economic activity, and well-being.

A final reflection relates to the need for geopolitical and socioeconomic coordination between countries, with emphasis on underdeveloped countries [46,47]. Up until now, during the crisis, some actions point in the opposite direction of cooperation [8] and others in favor [48]. If the $\mathrm{CO}_{2}$

\footnotetext{
4 The main reason for this phenomenon is the priority dispatch for RES to meet reduced demand.
} 
emissions rebound and get back to its long-run growth trajectory, the chances to accomplish the Paris climate goals will remain meager [49]. More broadly, "the world is not on track to achieve human development-related Sustainable Development Goals by 2030" [50]. Perhaps the pandemic is forcing us to devise more radical solutions to our energy and climate problems, as well as our social and economic predicaments more generally.

Author Contributions: Conceptualization, C.G.M.; investigation, C.G.M., I.S., N.B.A.; writing-original draft preparation, C.G.M.; writing-review and editing, C.G.M. and N.B.A.; supervision, I.S. All authors have read and agreed to the published version of the manuscript.

Funding: The first author (C.G.M.) was funded by R\&D ANEEL/CESP/IEE, grant numbers 00061-0054/2016 and R\&D ANEEL/ENEL/IEE, grant numbers 0121/2017-SPE/ANEEL.

Acknowledgments: The authors would like to thank Gabriel Konzen and Giorgio Spagarino for their useful comments.

Conflicts of Interest: The authors declare no conflict of interest. The funders had no role in the design of the study; in the collection, analyses, or interpretation of data; in the writing of the manuscript, or in the decision to publish the results.

\section{References}

[1] IEA, Global Energy Review 2020. The impacts of the Covid-19 crisis on global energy demand and CO2 emissions., 2020. https://www.iea.org/reports/global-energy-review-2020.

[2] C. Le Quéré, R.B. Jackson, M.W. Jones, A.J.P. Smith, S. Abernethy, R.M. Andrew, A.J. De-gol, D.R. Willis, Y. Shan, J.G. Canadell, P. Friedlingstein, F. Creutzig, G.P. Peters, Temporary reduction in daily global CO2 emissions during the COVID-19 forced confinement, Nat. Clim. Chang. (2020) 1-8. https://doi.org/10.1038/s41558-020-0797-x.

[3] W. Hicks, Declining Renewable Costs Drive Focus on Energy Storage, 2020. https://www.nrel.gov/news/features/2020/declining-renewable-costs-drive-focus-on-energy-storage.ht $\mathrm{ml}$.

[4] IRENA, RENEWABLE POWER GENERATION COSTS IN 2018, Abu Dhabi, 2019. https://www.irena.org/publications/2019/May/Renewable-power-generation-costs-in-2018.

[5] IRENA, Global Renewables Outlook: Energy Transformation 2050, Abu Dhabi, 2020. file:///C:/Users/Administrator/Downloads/IRENA_Global_Renewables_Outlook_2020.pdf.

[6] United Nations Environment Programme, Transforming the energy system-a post-COVID-19 win-win for people and (2020). https://www.unenvironment.org/news-and-stories/story/transforming-energy-system-post-covid-19-w in-win-people-and-planet.

[7] D. Rosenbloom, J. Markard, A COVID-19 recovery for climate, Science (80-. ). 368 (2020) 447. https://doi.org/10.1126/SCIENCE.ABC4887.

[8] W. Kanda, P. Kivimaa, What opportunities could the COVID-19 outbreak offer for sustainability transitions research on electricity and mobility?, Energy Res. Soc. Sci. 68 (2020) 101666. https://doi.org/10.1016/j.erss.2020.101666.

[9] Z. Csereklyei, D.I. Stern, Global energy use: Decoupling or convergence?, Energy Econ. 51 (2015). https://doi.org/10.1016/j.eneco.2015.08.029.

[10] P.J. Burke, Z. Csereklyei, Understanding the energy-GDP elasticity: A sectoral approach, Energy Econ. 58 (2016) 199-210. https://doi.org/10.1016/j.eneco.2016.07.004.

[11] D.I. Stern, R. Gerlagh, P.J. Burke, Modeling the emissions-income relationship using long-run growth rates, Environ. Dev. Econ. (2017) 1-26. https://doi.org/10.1017/S1355770X17000109. 
[12] J.E. Stiglitz, On a Post-COVID-19 Economy, Big $\quad$ Tech. (2020). https://www.cigionline.org/big-tech/joseph-stiglitz-post-covid-19-economy.

[13] V. Smil, The long slow rise of solar and wind, Sci. Am. $310 \quad(2014)$ 52-57. https://doi.org/10.1038/scientificamerican0114-52.

[14] BP, Statistical Review of World Energy 2020, London, 2020. https:/www.bp.com/content/dam/bp/business-sites/en/global/corporate/pdfs/energy-economics/statist ical-review/bp-stats-review-2020-full-report.pdf?utm_source=BP_Global_GroupCommunications_UK_ external\&utm_medium=email\&utm_campaign=11599394_Statistical Revi.

[15] M.A. Green, How Did Solar Cells Get So Cheap?, Joule. 3 (2019) 631-633. https://doi.org/10.1016/j.joule.2019.02.010.

[16] T. Mylenka, B. Novyk, Impact of Covid-19 on the global energy sector, PV Mag. (2020). https://www.pv-magazine.com/2020/04/24/impact-of-covid-19-on-the-global-energy-sector/.

[17] J. Odeck, K. Johansen, Elasticities of fuel and traffic demand and the direct rebound effects: An econometric estimation in the case of Norway, Transp. Res. Part A Policy Pract. 83 (2016) 1-13. https://doi.org/10.1016/j.tra.2015.10.003.

[18] N.K. Naqvi, M.A. Quddus, M.P. Enoch, Do higher fuel prices help reduce road traffic accidents?, Accid. Anal. Prev. 135 (2020) 105353. https://doi.org/10.1016/j.aap.2019.105353.

[19] D.G. Baur, N. Todorova, Automobile manufacturers, electric vehicles and the price of oil, Energy Econ. 74 (2018) 252-262. https://doi.org/10.1016/j.eneco.2018.05.034.

[20] C. Thiel, A. Tsakalidis, Will Electric Vehicles Be Killed ( again ) or Are They the Next Mobility Killer App?, (2020).

[21] N. Wang, L. Tang, H. Pan, A global comparison and assessment of incentive policy on electric vehicle promotion, Sustain. Cities Soc. 44 (2019) 597-603. https://doi.org/10.1016/j.scs.2018.10.024.

[22] Y. Wang, D. Sperling, G. Tal, H. Fang, China's electric car surge, Energy Policy. 102 (2017) 486-490. https://doi.org/10.1016/j.enpol.2016.12.034.

[23] IEA, Renewable Energy Market Update. Outlook for 2020 and 2021., 2020. https://webstore.iea.org/download/direct/2999.

[24] I.H. Shah, C. Hiles, B. Morley, How do oil prices, macroeconomic factors and policies affect the market for renewable energy?, Appl. Energy. 215 (2018) 87-97. https://doi.org/10.1016/j.apenergy.2018.01.084.

[25] H. Cao, L. Guo, L. Zhang, Does oil price uncertainty affect renewable energy firms' investment? Evidence from listed firms in China, Financ. Res. Lett. (2019) 1-7. https://doi.org/10.1016/j.frl.2019.06.003.

[26] R. Ferrer, S.J.H. Shahzad, R. López, F. Jareño, Time and frequency dynamics of connectedness between renewable energy stocks and crude oil prices, Energy Econ. 76 (2018) 1-20. https://doi.org/10.1016/j.eneco.2018.09.022.

[27] H. Zhang, G. Cai, D. Yang, The impact of oil price shocks on clean energy stocks: Fresh evidence from multi-scale perspective, Energy. 196 (2020) 117099. https://doi.org/10.1016/j.energy.2020.117099.

[28] A. Dutta, R.K. Jana, D. Das, Do green investments react to oil price shocks? Implications for sustainable development, J. Clean. Prod. (2020) 121956. https://doi.org/10.1016/j.jclepro.2020.121956.

[29] A. Sánchez, M. Martín, Optimal renewable production of ammonia from water and air, J. Clean. Prod. 178 (2018) 325-342. https://doi.org/10.1016/j.jclepro.2017.12.279.

[30] J. Baffes, W.C. Koh, Mixed results for fertilizers amid COVID-19 panic, World Bank Blog. (2020). https://blogs.worldbank.org/opendata/mixed-results-fertilizers-amid-covid-19-panic. 
[31] The World Bank, Monthly prices (xls), Commod. Mark. (2020). https://www.worldbank.org/en/research/commodity-markets (accessed November 7, 2020).

[32] H. Benchekroun, G. van der Meijden, C. Withagen, An oligopoly-fringe non-renewable resource game in the presence of a renewable substitute, J. Econ. Dyn. Control. 105 (2019) 1-20. https://doi.org/10.1016/j.jedc.2019.05.014.

[33] G. van der Meijden, C. Withagen, Limit pricing, climate policies, and imperfect substitution, Resour. Energy Econ. 58 (2019) 101118. https://doi.org/10.1016/j.reseneeco.2019.101118.

[34] D. Ansari, OPEC, Saudi Arabia, and the shale revolution: Insights from equilibrium modelling and oil politics, Energy Policy. 111 (2017) 166-178. https://doi.org/10.1016/j.enpol.2017.09.010.

[35] J. Hiller, Few U.S. shale firms can withstand prolonged oil price war, REUTERS. (2020). https://www.reuters.com/article/us-global-oil-shale-costs-analysis/few-u-s-shale-firms-can-withstandprolonged-oil-price-war-idUSKBN2130HL.

[36] L. Araujo Rodrigues, I. Luís Sauer, Exploratory assessment of the economic gains of a pre-salt oil field in Brazil, Energy Policy. 87 (2015) 486-495. https://doi.org/10.1016/j.enpol.2015.09.036.

[37] Alberta, Spotlight - Oil Sands Industry Adjusts to Lower Oil Prices, (2020).

[38] R.F. Aguilera, Production costs of global conventional and unconventional petroleum, Energy Policy. 64 (2014) 134-140. https://doi.org/10.1016/j.enpol.2013.07.118.

[39] P. Bhagwat, Identifying impacts of COVID-19 on the Indian Power Sector, (2020). https://fsr.eui.eu/identifying-impacts-of-covid-19-on-the-indian-power-sector/.

[40] A. Feil, COVID-19 and the Brazilian Electricity Sector, FSR Glob. (2020). https://fsr.eui.eu/covid-19-and-the-brazilian-electricity-sector/.

[41] F. Fuso Nerini, J. Tomei, L.S. To, I. Bisaga, P. Parikh, M. Black, A. Borrion, C. Spataru, V. Castán Broto, G. Anandarajah, B. Milligan, Y. Mulugetta, Mapping synergies and trade-offs between energy and the Sustainable Development Goals, Nat. Energy. 3 (2018) 10-15. https://doi.org/10.1038/s41560-017-0036-5.

[42] R. York, Why Petroleum Did Not Save the Whales, Socius Sociol. Res. a Dyn. World. 3 (2017) 237802311773921. https://doi.org/10.1177/2378023117739217.

[43] B.K. Sovacool, How long will it take? Conceptualizing the temporal dynamics of energy transitions, Energy Res. Soc. Sci. 13 (2016) 202-215. https://doi.org/10.1016/J.ERSS.2015.12.020.

[44] D. Coady, I. Parry, L. Sears, B. Shang, How Large Are Global Fossil Fuel Subsidies?, World Dev. 91 (2017) 11-27. https://doi.org/10.1016/j.worlddev.2016.10.004.

[45] R. Galvin, N. Healy, The Green New Deal in the United States: What it is and how to pay for it, Energy Res. Soc. Sci. 67 (2020). https://doi.org/10.1016/j.erss.2020.101529.

[46] F. Biermann, K. Abbott, S. Andresen, K. Backstrand, S. Bernstein, M.M. Betsill, H. Bulkeley, B. Cashore, J. Clapp, C. Folke, A. Gupta, J. Gupta, P.M. Haas, A. Jordan, N. Kanie, T. Kluvankova-Oravska, L. Lebel, D. Liverman, J. Meadowcroft, R.B. Mitchell, P. Newell, S. Oberthur, L. Olsson, P. Pattberg, R. Sanchez-Rodriguez, H. Schroeder, A. Underdal, S.C. Vieira, C. Vogel, O.R. Young, A. Brock, R. Zondervan, Navigating the Anthropocene: Improving Earth System Governance, Science (80-. ). 335 (2012) 1306-1307. https://doi.org/10.1126/science.1217255.

[47] B.K. Sovacool, M.H. Dworkin, Global energy justice: Problems, principles, and practices, (2014) 391. https://doi.org/10.1017/CBO9781107323605.

[48] H. Yaffe, The world rediscovers Cuban medical internationalism, LSE. (2020). https://blogs.lse.ac.uk/latamcaribbean/2020/04/08/the-world-rediscovers-cuban-medical-internationalis $\mathrm{m} /$ (accessed December 7, 2020). 


\section{1 of 11}

[49] E. Bovari, O. Lecuyer, F. Mc Isaac, Debt and damages: What are the chances of staying under the $2^{\circ} \mathrm{C}$ warming threshold?, Int. Econ. 155 (2018) 92-108. https://doi.org/10.1016/j.inteco.2018.02.002.

[50] J.D. Moyer, S. Hedden, Are we on the right path to achieve the sustainable development goals?, World Dev. 127 (2020) 104749. https://doi.org/10.1016/j.worlddev.2019.104749. 